\title{
Tyrosine modification increases the affinity of gastrin for ferric ions
}

\author{
Graham S. Baldwin *iD and loulia Sims
}

\begin{abstract}
The peptide hormone gastrin ${ }_{17}$, which occurs naturally in both tyrosine sulphated and unsulphated forms, binds two ferric ions with pM affinities. The aim of this study was to investigate the hypothesis that sulphation or phosphorylation of gastrin 17 altered ferric ion binding, and/or affinity for the CCK1 or CCK2 receptor. To investigate the effect of tyrosine modification on ferric ion binding, the changes in absorbance of gastrin ${ }_{17}$, gastrin ${ }_{17} \mathrm{SO}_{4}$ and gastrin ${ }_{17} \mathrm{PO}_{4}$ on addition of $\mathrm{Fe}^{3+}$ ions were monitored. Binding of gastrin ${ }_{17}$, gastrin ${ }_{17} \mathrm{SO}_{4}$ and gastrin ${ }_{17} \mathrm{PO}_{4}$ to the human $\mathrm{CCK} 1$ and CCK2 receptors was assessed by competition with [ $\left.{ }^{125} \mathrm{l}\right]$-Bolton and Hunter-labelled cholecystokinin 8 in transiently transfected COS cells. Tyrosine sulphation or phosphorylation increased the affinity of gastrin ${ }_{17}$ for the first ferric ion bound from 267 to 83 pM and 14 pM, respectively, but had no effect on the stoichiometry of ferric ion binding. In contrast the affinity of gastrin ${ }_{17}$ for the second ferric ion bound was reduced from $94 \mathrm{pM}$ to $7.32 \mu \mathrm{M}$ and $671 \mathrm{nM}$, respectively. While sulphation of gastrin ${ }_{17}$ increased its affinity for the CCK2 receptor approximately 50 fold, phosphorylation had no effect on receptor binding. These results demonstrate that tyrosine modification may have profound effects on the interaction of gastrins with ferric ions and with the CCK2 receptor.
\end{abstract}

Keywords: Gastrin, Ferric, Iron, Phosphorylation, Sulphation

\section{Background}

The classical gastrointestinal hormone gastrin ${ }_{17}$ (ZGPWLEEEEEAYGWMDFamide, Gamide) was first recognized by its ability to stimulate gastric acid secretion (Dockray et al. 2001). Human gastrin is initially synthesized as a 101 amino acid preprohormone, which is processed via the 80 amino acid prohormone progastrin, to various non-amidated precursors including glycineextended gastrin $_{17}$ (ZGPWLEEEEEAYGWMDFG, Ggly) (Dockray et al. 2001). While Gamide stimulates proliferation in the gastric mucosa (Koh et al. 1999), progastrin and Ggly are important growth factors for the colorectal mucosa (Aly et al. 2004). The related hormone cholecystokinin (CCK), which has the same amidated C-terminal pentapeptide sequence as gastrin ${ }_{17}$, is responsible for gallbladder contraction and pancreatic enzyme secretion (Miyasaka and Funakoshi 2003).

*Correspondence: grahamsb@unimelb.edu.au Department of Surgery, Austin Health, The University of Melbourne, Heidelberg, VIC 3084, Australia
The receptors for CCK (CCK1 receptor) and Gamide (CCK2 receptor) are both members of the seven transmembrane domain family, and share $50 \%$ sequence identity (Aly et al. 2004; Shulkes and Baldwin 1997). The CCK1 receptor is found on pancreatic acini and has a 1000 -fold higher affinity for sulphated $\mathrm{CCK}_{8}\left(\mathrm{CCK}_{8} \mathrm{SO}_{4}\right)$ than for unsulphated $\mathrm{CCK}_{8}$. However, sulphation of $\mathrm{CCK}_{8}$ does not greatly affect its affinity for the CCK2 receptor, which is found in the gastric mucosa and in the brain (Shulkes and Baldwin 1997). Neither the CCK1 nor the CCK2 receptor recognizes non-amidated forms of CCK or gastrin, but the receptors can be readily distinguished with several selective antagonists (Shulkes and Baldwin 1997).

Gastrins such as Ggly and Gamide bind two ferric ions (Baldwin et al. 2001), the first to Glu7 and the second to Glu8 and Glu9 (Baldwin et al. 2015; Pannequin et al. 2002). Ferric ions are essential for the biological activity of Ggly as a stimulant of cell proliferation and migration (Pannequin et al. 2002), but are not required for the biological activity of Gamide (Pannequin et al. 2004). For example, treatment with the iron chelator

\section{Springer}

(C) 2015 Baldwin and Sims. This article is distributed under the terms of the Creative Commons Attribution 4.0 International License (http://creativecommons.org/licenses/by/4.0/), which permits unrestricted use, distribution, and reproduction in any medium, provided you give appropriate credit to the original author(s) and the source, provide a link to the Creative Commons license, and indicate if changes were made. 
desferrioxamine, or substitution of Glu7 with Ala, completely blocked the biological activity of Ggly (Pannequin et al. 2002), but had no effect on the biological activity of Gamide (Pannequin et al. 2004).

Sulphation of $\mathrm{CCK}_{8}$ on the sole tyrosine residue greatly increases receptor binding and biological potency (Jensen et al. 1981). Tyrosine sulphation or phosphorylation of $\mathrm{CCK}_{8}$ increased the stoichiometry of ferric ion binding from 1 to 2, without greatly affecting the affinity (Baldwin et al. 2008). Gastrins also occur in sulphated and unsulphated forms (Dockray et al. 2001), and the sulphated form predominates in the fetal pancreas (Brand et al. 1984). Gastrin can also be phosphorylated by the EGF receptor tyrosine kinase in vitro (Baldwin et al. 1983), but phosphorylated gastrins have not been reported to occur naturally. The aim of the present study was to determine whether or not sulphation or phosphorylation of gas$\operatorname{trin}_{17}$ altered ferric ion binding or affinity for the CCK1 or CCK2 receptor. Since non-amidated forms of gastrin require ferric ions for activity, a change in affinity for ferric ions on modification of the tyrosine residue of gastrins might have profound effects on their biological activity.

\section{Methods \\ Peptides}

Gastrin $_{17}$ and sulphated gastrin 17 (95 and $96 \%$ pure, respectively) were purchased from Bachem (Bubendorf, Switzerland). Phosphorylated gastrin 17 (85\% pure) was from Mimotopes (Clayton, Australia). All peptides had a pyroglutamyl residue at their $\mathrm{N}$-terminus and were $\mathrm{C}$-terminally amidated. The impurities consisted of water and salts.

\section{Absorption spectroscopy}

The absorption of peptides $(10 \mu \mathrm{M}$ in $10 \mathrm{mM}$ sodium acetate $(\mathrm{pH} 4.0)$ containing $100 \mathrm{mM} \mathrm{NaCl}$ and $0.005 \%$ Tween 20) at $280 \mathrm{~nm}$ in the presence of increasing concentrations of ferric ions from 2.5 to $50 \mu \mathrm{M}$ was measured against a buffer blank, in $1 \mathrm{ml}$ quartz cuvettes thermostatted at $298 \mathrm{~K}$, with a Cary 5 spectrophotometer (Varian, Mulgrave, Australia).

\section{Receptor binding assay}

Binding of ligands to the human CCK1 or CCK2 receptors on transiently transfected COS-7 cells was measured by competition with sulfated $\left[{ }^{125} \mathrm{I}\right]$-Bolton and Hunter labelled- $\mathrm{CCK}_{8}(50,000 \mathrm{cpm} /$ well, Amersham Biosciences, Castle Hill, Australia) as described previously (Baldwin et al. 2008).

\section{Curve fitting and statistics}

Data [expressed as mean \pm standard error of the means (SEM)] for the binding of ferric ions to gastrins were fitted to a two-site ordered model with the program BioEqs (Royer 1993; Royer et al. 1990). Receptor binding data were analyzed by one-way analysis of variance, followed by Bonferroni's $t$ test. Differences with $P$ values $<0.05$ were considered significant.

\section{Results and discussion}

\section{Changes in absorbance on binding of ferric ions} to tyrosine-modified gastrin ${ }_{17}$

The effect of addition of $\mathrm{Fe}^{3+}$ ions on the absorption spectrum of gastrin ${ }_{17}$, gastrin ${ }_{17} \mathrm{SO}_{4}$ and gastrin ${ }_{17} \mathrm{PO}_{4}$ was first investigated by absorption spectroscopy. $\mathrm{A} \mathrm{pH}$ value of 4.0 was chosen in order to avoid any problems with precipitation of ferric hydroxides, and to allow direct comparison with previous studies. As reported previously (Baldwin et al. 2001, 2015) the absorption of gastrin $_{17}$ at $280 \mathrm{~nm}$ increased to a maximum of $220 \%$ after the addition of $2.0 \mathrm{~mol}$ ferric chloride/mol peptide (Fig. 1a). Fitting of the absorption data to a two-site ordered model with the program BioEqs gave values for $\mathrm{K}_{\mathrm{d}} 1$ and $\mathrm{K}_{\mathrm{d}} 2$ of 267 and $94 \mathrm{pM}$, respectively, in good agreement with the values determined previously (Baldwin et al. 2015) (Table 1). The increase in absorption of gastrin ${ }_{17} \mathrm{SO}_{4}$ (Fig. 1b) on addition of ferric ions was more gradual than for gastrin ${ }_{17}$, and in the case of gas$\operatorname{trin}_{17} \mathrm{PO}_{4}$ a slight decrease in absorption was initially observed (Fig. 1c). Nevertheless the absorption for both gastrin ${ }_{17} \mathrm{SO}_{4}$ and gastrin ${ }_{17} \mathrm{PO}_{4}$ finally reached maxima of $195 \%$ to $220 \%$ after the addition of 2-3 mol ferric chloride/mol peptide. Fitting of the absorption data to a twosite ordered model with the program BioEqs gave values for $K_{d} 1$ and $K_{d} 2$ of $83 p M$ and $7.32 \mu \mathrm{M}$, respectively, for gastrin ${ }_{17} \mathrm{SO}_{4}$, and of $14 \mathrm{pM}$ and $671 \mathrm{nM}$, respectively, for gastrin $_{17} \mathrm{PO}_{4}$ (Table 1).

This data indicates that, although tyrosine sulphation or phosphorylation had no effect on the stoichiometry of ferric ion binding, the affinity of gastrin for the first ferric ion was enhanced, and for the second ferric ion was reduced, by modification of the tyrosine side chain. The possibility that the hydroxyl group of the tyrosine is itself a ligand for the second ferric ion does not appear to be likely as XAFS data suggested that three of the five glutamate side chains act as ferric ion ligands (Baldwin et al. 2015). A more likely explanation is that the bulky sulphate and phosphate groups occupy the ferric ion binding site and prevent access of more than one ferric ion.

The concentrations of gastrins and of ferric ions used in the above experiments were supra-physiological. The concentration of gastrins was chosen as the minimum concentration that gave a reproducible change in absorbance on addition of ferric ions. Nevertheless our previous publications indicate that the binding of ferric ions to gastrin at physiological concentrations is essential for 


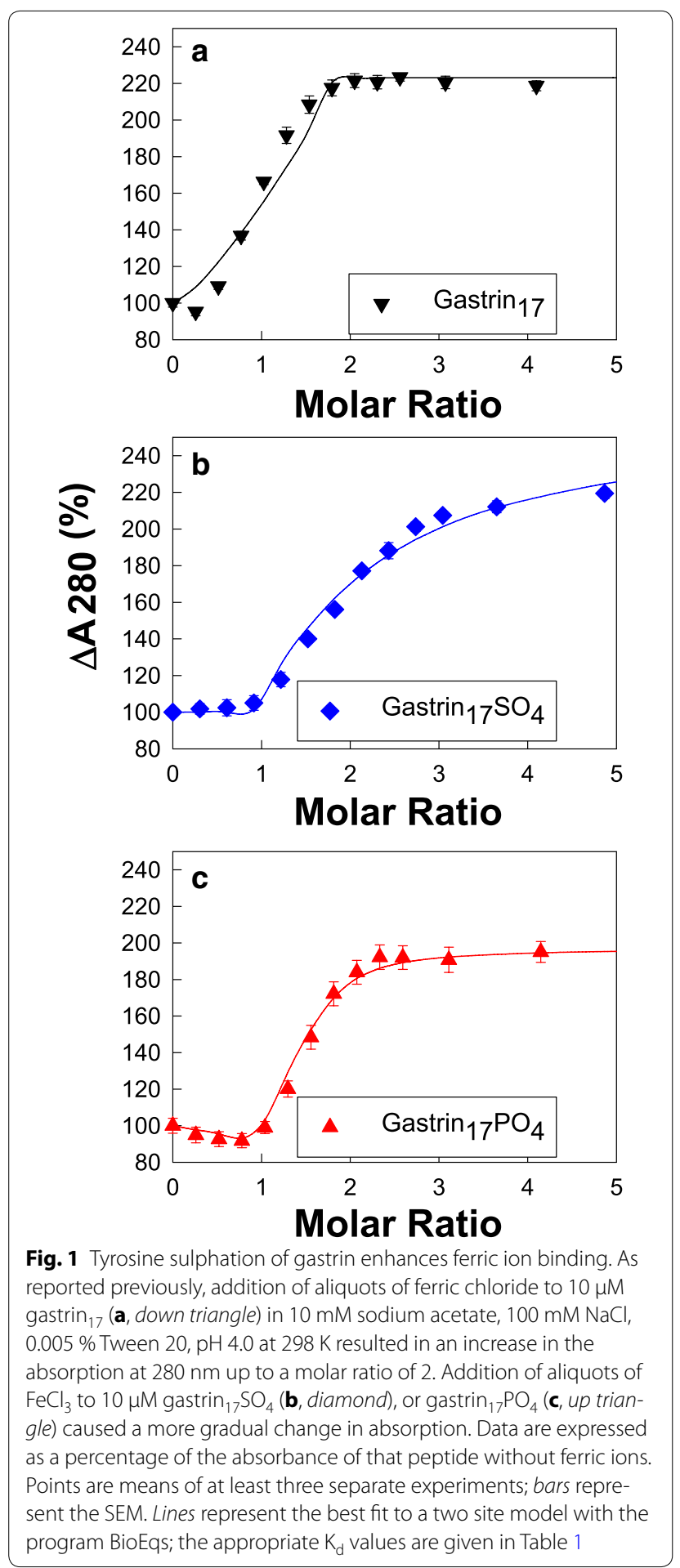

biological function. Thus mutation of the glutamate residues essential for binding ferric ions abrogates the biological activity of Ggly as a stimulant of cell proliferation and migration (Pannequin et al. 2002). Similarly removal of ferric ions with the iron chelator desferrioxamine
Table 1 Binding of ferric ions by gastrin ${ }_{17}, \mathrm{CCK}_{8}$ and their derivatives

\begin{tabular}{|c|c|c|c|c|c|}
\hline & \multirow[t]{2}{*}{ Reference } & \multicolumn{4}{|l|}{ Absorption } \\
\hline & & $\mathrm{K}_{\mathrm{d}} 1$ (pM) & $K_{d} 2(p M)$ & $\begin{array}{l}A_{280} \\
\text { Site } 1 \\
(\%)\end{array}$ & $\begin{array}{l}A_{280} \\
\text { Site } 2 \\
(\%)\end{array}$ \\
\hline Gastrin $_{17}$ & & 267 & 94 & 100 & 223 \\
\hline Gastrin $_{17}$ & $\begin{array}{l}\text { Baldwin et al. } \\
\quad(2015)\end{array}$ & 300 & 85 & 100 & 313 \\
\hline Gastrin $_{17} \mathrm{SO}_{4}$ & & 83 & $7,320,000$ & 88 & 259 \\
\hline Gastrin $_{17} \mathrm{PO}_{4}$ & & 14 & 671,000 & 98 & 215 \\
\hline $\mathrm{CCK}_{8}$ & $\begin{array}{l}\text { Baldwin et al. } \\
\quad(2008)\end{array}$ & Not detected & & & \\
\hline $\mathrm{CCK}_{8} \mathrm{SO}_{4}$ & $\begin{array}{l}\text { Baldwin et al. } \\
\quad(2008)\end{array}$ & Not detected & & & \\
\hline $\mathrm{CCK}_{8} \mathrm{PO}_{4}$ & $\begin{array}{l}\text { Baldwin et al. } \\
\quad(2008)\end{array}$ & Cooperative & Cooperative & & $194^{\mathrm{a}}$ \\
\hline
\end{tabular}

The affinity of, and the percentage absorbance change at $280 \mathrm{~nm}$ on, the binding of the first and second ferric ions to gastrin ${ }_{17}$, gastrin ${ }_{17} \mathrm{SO}_{4}$ or gastrin ${ }_{17} \mathrm{PO}_{4}$ at $\mathrm{pH} 4.0$ were determined by fitting the mean data obtained in the absorbance experiments $(\mathrm{N}=3)$ described in the Fig. 1 legend to a two site ordered model with the program BioEqs

a The absorbance changes for $\mathrm{CCK}_{8}$ and its derivatives were measured at $275 \mathrm{nM}$ as the peptide contains tyrosine and phenylalanine, but no tryptophan, residues (Baldwin et al. 2008)

(Ferrand et al. 2010; Pannequin et al. 2002), or by competition with bismuth ions (Kovac et al. 2012; Pannequin et al. 2002), blocked the biological activity of Ggly in vitro and in vivo.

\section{Effect of tyrosine modification on CCK receptor binding}

The effect of tyrosine modification on the binding of gas$\operatorname{trin}_{17}$ to either human CCK1 or CCK2 receptors was then examined. Although sulphation of gastrin ${ }_{17}$ increased its affinity for the human CCK2 receptor, phosphorylation of gastrin ${ }_{17}$ had no effect on CCK2 receptor binding (Fig. $2 \mathrm{~b}$ ). The $\mathrm{IC}_{50}$ values for the binding of gastrin ${ }_{17}$, gas$\operatorname{trin}_{17} \mathrm{SO}_{4}$ and gastrin ${ }_{17} \mathrm{PO}_{4}$ to the CCK2 receptor were $61 \pm 32,1.2 \pm 0.4$ and $58 \pm 20 \mathrm{nM}$, respectively. The $\mathrm{IC}_{50}$ values for the binding of gastrin 17 were slightly higher than the values, which range from 0.94 to $6.4 \mathrm{nM}$, previously reported for the cloned human CCK2 receptor (Ito et al. 1993; Lee et al. 1993; Pisegna et al. 1992). The affinity of gastrin ${ }_{17} \mathrm{SO}_{4}$ for the cloned human CCK2 receptor does not appear to have been reported previously, but data for binding to dispersed gastric glands from the guinea pig fundus also suggest that sulphation increases the affinity for the CCK 2 receptor, in that case by a factor of tenfold, from 16 to $1.6 \mathrm{nM}$ (Praissman et al. 1983). Binding of gastrin 17 , gastrin ${ }_{17} \mathrm{SO}_{4}$ and gastrin ${ }_{17} \mathrm{PO}_{4}$ to the CCK1 receptor was not detected in our experiments (Fig. 2a). In the case of gastrin 17 this result agrees with the data of de Weerth and co-workers, who reported 


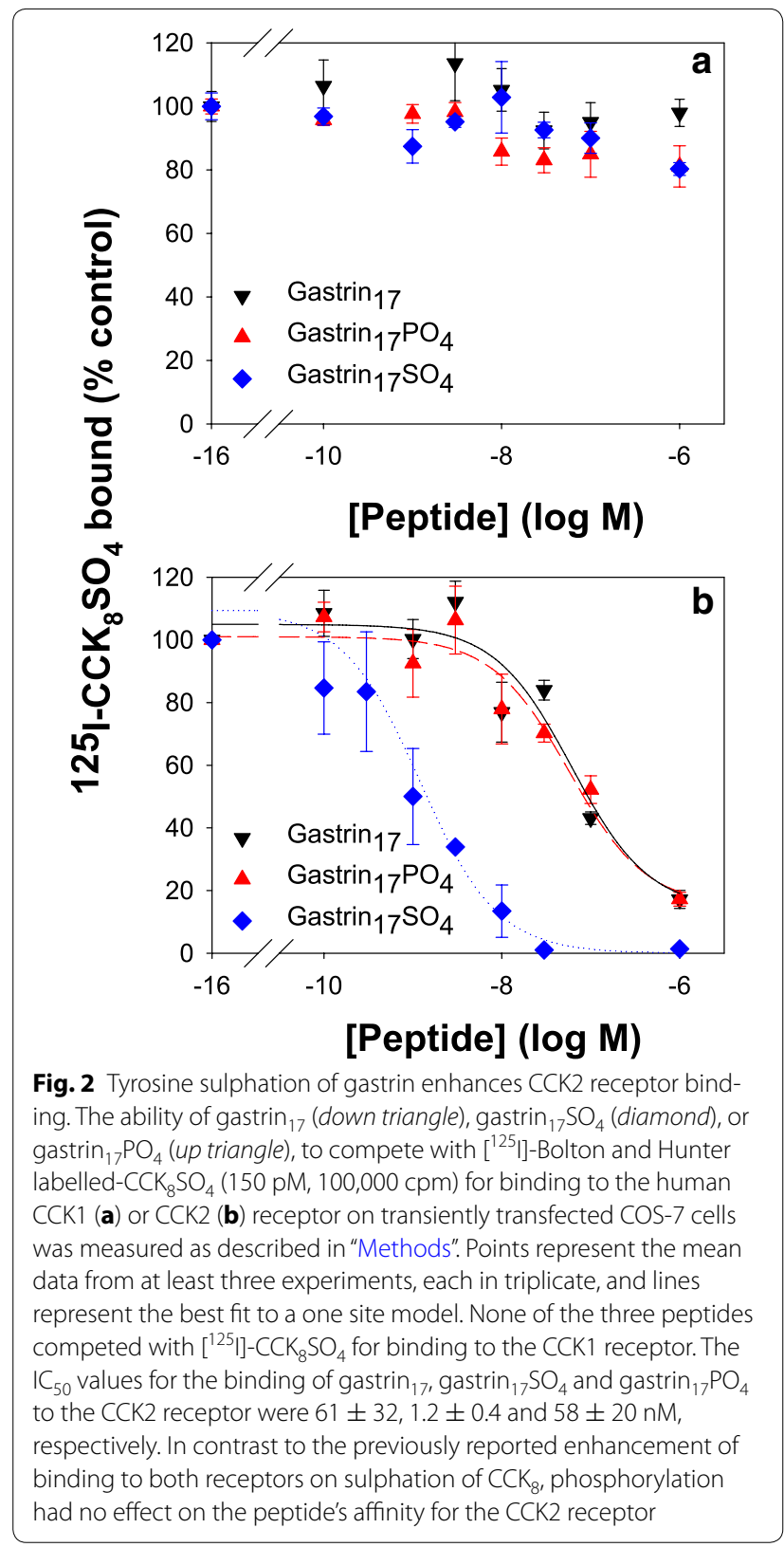

an $\mathrm{IC}_{50}$ value of $1.8 \mu \mathrm{M}$ (de Weerth et al. 1993); binding affinities of gastrin ${ }_{17} \mathrm{SO}_{4}$ and gastrin ${ }_{17} \mathrm{PO}_{4}$ for the CCK1 receptor do not appear to have been reported previously.

\section{Comparison with $\mathrm{CCK}_{8}$}

In contrast to $\mathrm{CCK}_{8}$, where tyrosine sulphation or phosphorylation increased the stoichiometry of ferric ion binding from 1 to 2 without greatly affecting the affinity (Baldwin et al. 2008), tyrosine sulphation or phosphorylation of gastrin ${ }_{17}$ had no effect on the stoichiometry of ferric ion binding, but enhanced the affinity of gastrin ${ }_{17}$ for the first ferric ion, and reduced the affinity for the second ferric ion. This difference is not unexpected as the gastrin binding site consists of three of the five glutamate residues, while the $\mathrm{CCK}_{8} \mathrm{SO}_{4}$ binding site involves the two aspartate residues, and the $\mathrm{CCK}_{8} \mathrm{PO}_{4}$ binding site the phosphate group itself (Baldwin et al. 2008). In terms of receptor binding, tyrosine sulphation enhanced the affinity, while phosphorylation reduced the affinity, of $\mathrm{CCK}_{8}$ for both the CCK1 and CCK2 receptors (Baldwin et al. 2008). In contrast, while tyrosine sulphation enhanced the affinity of gastrin 17 for the CCK2 receptor, phosphorylation had no effect. Although the generalization that modification of tyrosine profoundly affects the binding of ferric ions is valid, the differences between two such closely related peptides as gastrin ${ }_{17}$ and $\mathrm{CCK}_{8}$ indicate that the exact binding details will have to be determined for each peptide individually.

\section{Conclusions}

While tyrosine sulphation or phosphorylation of gastrin ${ }_{17}$ had no effect on the stoichiometry of $\mathrm{Fe}^{3+}$ ion binding, the affinity for the first ferric ion bound was increased from 267 to 83 pM and $14 \mathrm{pM}$, respectively. Sulphation of gastrin ${ }_{17}$ increased its affinity for the CCK2 receptor approximately 50 fold, but phosphorylation had no effect on receptor binding. These results imply that tyrosine modification may have profound effects on the biological activities of gastrins.

\section{Abbreviations \\ CCK: cholecystokinin; DMEM: Dulbecco's Modified Eagle Medium; Gamide: amidated gastrin $_{17} ;$ Ggly: glycine-extended gastrin ${ }_{17}$.}

\section{Authors' contributions}

GSB conceived the study, conducted the absorbance experiments, and drafted the manuscript. IS participated in the design of the study and performed the binding experiments. Both authors read and approved the final manuscript.

\section{Acknowledgements}

This work was supported in part by grants from the National Health and Medical Research Council of Australia $(454322,1020983)$.

\section{Competing interests}

The authors declare that they have no competing interests. The research did not involve animals or human participants.

Received: 9 November 2015 Accepted: 15 December 2015

Published online: 24 December 2015

\section{References}

Aly A, Shulkes A, Baldwin GS (2004) Gastrins, cholecystokinins and gastrointestinal cancer. Biochim Biophys Acta 1704:1-10

Baldwin GS, Knesel J, Monckton JM (1983) Phosphorylation of gastrin-17 by epidermal growth factor-stimulated tyrosine kinase. Nature 301:435-437 Baldwin GS, Curtain CC, Sawyer WH (2001) Selective, high-affinity binding of ferric ions by glycine-extended gastrin(17). Biochemistry 40:10741-10746 
Baldwin GS, Bailey MF, Shehan BP, Sims I, Norton RS (2008) Tyrosine modification enhances metal-ion binding. Biochem J 416:77-84

Baldwin GS, George GN, Pushie MJ (2015) High Affinity Binding of Indium and Ruthenium lons by Gastrins. PLoS one 10:e0140126. doi:10.1371/journal. pone.0140126

Brand SJ, Andersen BN, Rehfeld JF (1984) Complete tyrosine-O-sulphation of gastrin in neonatal rat pancreas. Nature 309:456-458

de Weerth A, Pisegna JR, Huppi K, Wank SA (1993) Molecular cloning, functional expression and chromosomal localization of the human cholecystokinin type A receptor. Biochem Biophys Res Commun 194:811-818

Dockray GJ, Varro A, Dimaline R, Wang T (2001) The gastrins: their production and biological activities. Annu Rev Physiol 63:119-139

Ferrand A, Lachal S, Bramante G, Kovac S, Shulkes A, Baldwin GS (2010) Stimulation of proliferation in the colorectal mucosa by gastrin precursors is blocked by desferrioxamine. Am J Physiol Gastrointest Liver Physiol 299:G220-227

Ito M et al (1993) Functional characterization of a human brain cholecystokinin-B receptor. A trophic effect of cholecystokinin and gastrin. J Biol Chem 268:18300-18305

Jensen SL, Holst JJ, Nielsen OV, Rehfeld JF (1981) Effect of sulfation of CCK-8 on its stimulation of the endocrine and exocrine secretion from the isolated perfused porcine pancreas. Digestion 22:305-309

Koh TJ, Dockray GJ, Varro A, Cahill RJ, Dangler CA, Fox JG, Wang TC (1999) Overexpression of glycine-extended gastrin in transgenic mice results in increased colonic proliferation. J Clin Invest 103:1119-1126

Kovac S, Loh SW, Lachal S, Shulkes A, Baldwin GS (2012) Bismuth ions inhibit the biological activity of non-amidated gastrins in vivo. Biochem Pharmacol 83:524-530
Lee YM, Beinborn M, McBride EW, Lu M, Kolakowski LF Jr, Kopin AS (1993) The human brain cholecystokinin-B/gastrin receptor. Cloning and characterization. J Biol Chem 268:8164-8169

Miyasaka K, Funakoshi A (2003) Cholecystokinin and cholecystokinin receptors. J Gastroenterol 38:1-13

Pannequin J, Barnham KJ, Hollande F, Shulkes A, Norton RS, Baldwin GS (2002) Ferric ions are essential for the biological activity of the hormone glycineextended gastrin. J Biol Chem 277:48602-48609

Pannequin J, Tantiongco JP, Kovac S, Shulkes A, Baldwin GS (2004) Divergent roles for ferric ions in the biological activity of amidated and non-amidated gastrins. J Endocrinol 181:315-325

Pisegna JR, de Weerth A, Huppi K, Wank SA (1992) Molecular cloning of the human brain and gastric cholecystokinin receptor: structure, functional expression and chromosomal localization. Biochem Biophys Res Commun 189:296-303

Praissman M, Walden ME, Pellecchia C (1983) Identification and characterization of a specific receptor for cholecystokinin on isolated fundic glands from guinea pig gastric mucosa using a biologically active 125I-CCK-8 probe. J Recept Res 3:647-665

Royer CA (1993) Improvements in the numerical analysis of thermodynamic data from biomolecular complexes. Anal Biochem 210:91-97

Royer CA, Smith WR, Beechem JM (1990) Analysis of binding in macromolecular complexes: a generalized numerical approach. Anal Biochem 191:287-294

Shulkes A, Baldwin GS (1997) Biology of gut cholecystokinin and gastrin receptors. Clin Exp Pharmacol Physiol 24:209-216

\section{Submit your manuscript to a SpringerOpen ${ }^{\odot}$ journal and benefit from:}

- Convenient online submission

- Rigorous peer review

- Immediate publication on acceptance

- Open access: articles freely available online

- High visibility within the field

- Retaining the copyright to your article

Submit your next manuscript at $>$ springeropen.com 